\title{
Erratum to: Suppression of apoptosis inhibitor c-FLIP selectively eliminates breast cancer stem cell activity in response to the anti-cancer agent, TRAIL
}

Luke Piggott ${ }^{1,2+}$, Nader Omidvar ${ }^{1+}$, Salvador Martí Pérez ${ }^{2}$, Rhiannon French ${ }^{1}$, Matthias Eberl ${ }^{2}$ and Richard WE Clarkson ${ }^{1 *}$

\section{Correction}

While compiling the article [1] one of the authors was inadvertently omitted from the author list. This author, Rhiannon French, has been included in the corrected author list above.

\section{Competing interests}

The authors declare that they have no competing interests.

\section{Authors' contributions}

LP was responsible for the design of the experiments, assembly of data and manuscript writing. NO was responsible for the design of experiments, data collection and manuscript writing. SMP developed a new assay. RF was responsible for the design and execution of experiments for one of the figures. ME handled data analysis and interpretation, funding of research and manuscript writing. $\mathrm{RC}$ was responsible for the conception and design of the study, data analysis and interpretation, manuscript writing, final approval of manuscript and funding of research. All authors have read and approved the manuscript for publication.

\section{Acknowledgements}

We thank Christien Gabriel and Dawn Roberts for technical support. This study was funded by a Tenovus PhD scholarship (LP), seed-corn funding from the Breast Cancer Campaign (RC) and additional part-funding from CR-UK (ME) and BBSRC (NO). RC and ME are RC-UK Research Fellows.

\section{Author details}

${ }^{1}$ Life Sciences Building, Cardiff University School of Biosciences, Museum Avenue, Cardiff CF10 3AX, Wales, UK. ²Department of Infection, Immunity and Biochemistry, Cardiff University School of Medicine, Heath Park Campus, Cardiff CF14 4XN, Wales, UK

Received: 28 May 2014 Accepted: 21 July 2014

Published online: 16 July 2015

\section{Reference}

1. Piggott L, Omidvar N, Martí Pérez S, Eberl M, Clarkson RWE. Suppression of apoptosis inhibitor c-FLIP selectively eliminates breast cancer stem cell activity in response to the anti-cancer agent, TRAll. Breast Canc Res. 2011;13:R88.

\footnotetext{
* Correspondence: clarksonr@cf.ac.uk

${ }^{\dagger}$ Equal contributors

'Life Sciences Building, Cardiff University School of Biosciences, Museum Avenue, Cardiff CF10 3AX, Wales, UK
}

\section{Submit your next manuscript to BioMed Central and take full advantage of: \\ - Convenient online submission \\ - Thorough peer review \\ - No space constraints or color figure charges \\ - Immediate publication on acceptance \\ - Inclusion in PubMed, CAS, Scopus and Google Scholar \\ - Research which is freely available for redistribution}

Submit your manuscript at

www.biomedcentral.com/submit
() Biomed Central

\section{() Biomed Central}

